
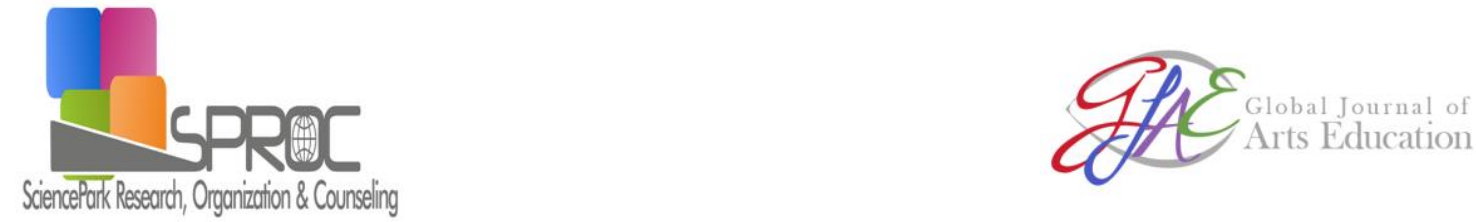

http://sproc.org/ojs/index.php/gjae

\title{
Desing in new media practices: A review on facebook ads as a
} social network

Seçil Ermiş *

Suggested Citation:

Journal of Arts Education 6

Global

Abstract

Seçil Ermiş,

E-mail address: 


\section{Introduction}

$\longrightarrow$ 
Duracell

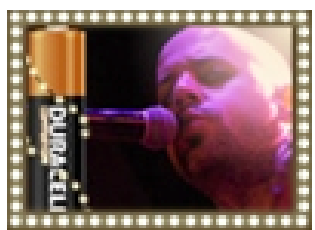

Like Daughtry? Like

Duracell!

的 Like $\cdot 534,569$ people like this. 


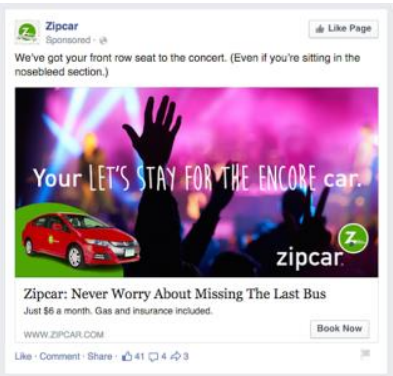




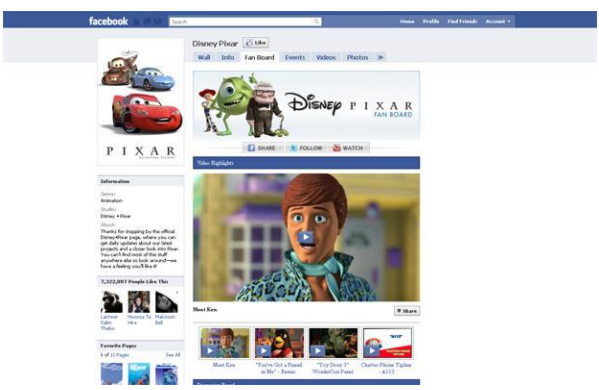

Image 3.

\section{Conclusion}




\section{References}

Graphic Design Layout.

International Student Edition Graphic Design Basics.

. Social Media Social Research

Strategy Sustaining Competitive Advantage in a Globalised

Context.

$$
\begin{gathered}
\text { Consumer Behavior. } \\
\text { Multimedya ve Görsel Tasarım } \\
\text { The Elements of Design. } \\
\text { The Language of Graphic Design } \\
\text { The New Digital Age. } \\
\text { The Facebook Era }
\end{gathered}
$$

Corporate Communication in the Internet Age

\section{Online resources}

